\title{
Examining the Relationship between Lean Supplier Relationship Management (LSRM) and Firm Performance: A Study on Manufacturing Companies in Ghana
}

\author{
Sheila Benah*, Yang Li \\ School of Economics and Management, Anhui University of Science and Technology, Huainan, China \\ Email: *benahenyo@yahoo.com, y321212@163.com
}

How to cite this paper: Benah, S., \& Li, Y. (2020). Examining the Relationship between Lean Supplier Relationship Management (LSRM) and Firm Performance: A Study on Manufacturing Companies in Ghana. Open Journal of Business and Management, 8 , 2423-2450.

https://doi.org/10.4236/ojbm.2020.86150

Received: September 17, 2020

Accepted: November 9, 2020

Published: November 12, 2020

Copyright $\odot 2020$ by author(s) and Scientific Research Publishing Inc. This work is licensed under the Creative Commons Attribution International License (CC BY 4.0).

http://creativecommons.org/licenses/by/4.0/

\section{Open Access}

\begin{abstract}
The main purpose of this research is to examine the relationship between Lean Supplier Relationship Management (LSRM) practices and the performance of manufacturing companies in Ghana. A close-ended questionnaire was used to collect the data for our analysis. A total of 200 questionnaires were returned and used for further analysis. IBM SPSS 25 and IBM AMOS 24 software were used to analyze the survey data. Structural Equation Modelling (SEM) approach was used to examine the relationship between the latent and manifest constructs. The structural results revealed positive significant effects of Supplier Flexibility (SF), Supply Partnership (SP), and Just-In-Time Delivery (JD) on performance of manufacturing companies in Ghana. The result analysis further indicated that JD has the highest positive effect on performance with an estimated path coefficient of 0.68 . The result also revealed the non-significant effect of Knowledge Sharing (KS) on performance of manufacturing companies in Ghana. The study seeks to add up to the already exiting literature on lean supply chain management and lean supplier relationship management on performance of manufacturing companies in Ghana. This research framework can be adopted by manufacturing companies in determining the implementation level of LSRM practices in their business processes. The study was conducted on cross-sectional basis and the results were based on quantitative analyze alone. Future research may use both quantitative and qualitative approaches. More studies can be done on the LSRM variables and their effect on manufacturing companies. Future studies can be conducted in other sectors, such as Human Resource sector, Warehouse sector and Transportation sector and their impact on firm performance as this study was limited to LSRM practices.
\end{abstract}




\section{Keywords}

LSRM Practices, Firm Performance, Supply Chain Management, Lean Management, Supplier Relationship Management, Ghana

\section{Introduction}

The "headache" of most business managers is to utilize its resources in the most effective way. The question running through most minds is "how do I use the limited resources I have to produce not only quantity but quality goods and services without any wastage." The search for an answer led to the development of a system called the "lean". The lean system has its roots in the automobile industry. History has it that $\mathrm{H}$. Ford was using a sort of lean management as early as 1920.

IMEP (2000) describes lean as a systematic approach for identifying and eliminating waste through continuous improvement by "flowing" the product at the pull of the customer in pursuit of perfection. Lean can be interpreted as "slim", because it seeks to eliminate the unnecessary and non-value added activities while maintaining and implementing the necessary activities. Lean focuses on value-added, and it can be achieved through constant evaluation on the improvement process.

The business world is characterized by highly excessive competition and most manufacturing firms must come up with creative ways to develop and produce new products. However, the stumbling block to achieve this goal is the problem of waste. Very high levels of wastes (non-value added activities) are confirmed to exist in the manufacturing companies. Several studies from various companies have confirmed that waste in manufacturing companies represents a relatively large percentage of production cost. The existences of a significant number of wastes in the manufacturing sector have depleted overall performance and productivity of the industry, and certain serious measures have to be taken to rectify the current situation (Aziz \& Hafez, 2013).

An important factor manufacturing firms should take into consideration is supply chain management. Suppliers play a huge role in this industry because of the impact it has on the firm both positively and negatively. Good quality, efficiency and customer satisfaction are some of the benefits a firm reaps if its supply relationship management is effective (SRM) (Ndubisi et al., 2005; Foerstl et al., 2016).

Manufacturing firms explore different ways to incorporate the lean system into the supplier relationship management system. This is done to reduce the seven wastes as suggested Balle et al. (2005). The seven wastes comprise of the waste of overproduction, the waste of waiting for parts to arrive, the waste of conveyance, the waste in processing, the waste of inventory, the waste of motion 
and the waste of rework.

Supplier relationship Management (SRM) has been one of the researched topics in lean management because it deals with the collaboration a firm has with its suppliers to maintain the continuous flow of the necessary inputs like materials, resources, parts and information. What remains a problem is the inadequacy of relevant literatures incorporating lean into the SRM. However this is an important factor because manufacturing firms need to build and maintain the right relationship with its suppliers in order to reduce cost and waste.

The purpose of this paper is to establish the relationship between LSRM and firm performance. It also seeks to explore the extent to which a manufacturing company factors or adopts LSRM in its business activities. The paper infuses the SRM and lean paradigms, and uses a well-developed assessment tool for measuring LSRM practices.

The paper has been structured in the following parts. The first part is the introduction, which seek to introduce the concept of the study. The second section is the literature review. This part goes in-depth into lean management, supplier relationship management. The third segment is the methodology that describes the measurement instrument used and the procedures used in this study. Results and discussion follows rightly after. This part explains the results into details after the analysis has been run. The conclusion sections which ends the paper, gives insight into the theoretical and practical implications of the study as well as recommendations.

\section{Literature Review}

\subsection{Lean Management}

Most people mistakenly believe that lean manufacturing originated from Japan (Toyota production systems to be specific), but H. Ford was already using some sort of lean management as early as 1920. Other businesses started to apply Ford ideas, but they soon realized that rigidity of Ford's system was a major hindrance to innovation. Later, Taiichi Ohno and kiichiro Toyota built on Ford's ideas to develop what is now known as Toyota production system (TPS).

Lean can be described as the identification of value and elimination of waste to improve the process or doing more productive work with less effort. Lean is about controlling the resources in accordance with the customers' needs and about reducing unnecessary waste, including the waste of time and material (Ehrlich, 2002). Lean is a systematic approach for identifying and eliminating waste through continuous improvement by "flowing" the product at the pull of the customer in pursuit of perfection (IMEP, 2000). Studies argue that a lean system is the superior way of producing manufactured goods. Rizzardo and Brooks (2008) note that the lean process itself almost always results in company growth due to the benefits gained of quicker deliveries, higher quality, and increased responsiveness to customers. 
Lean management is defined as a set of tools, principles, and production techniques that help in identification and elimination of waste through continuous improvements of the production process. Lean management began in production environments and is often described by a number of synonyms; Toyota production system, lean production, Lean manufacturing, and more

There are a variety of companies that have experienced the advantages of applying Lean in their manufacturing area. For instance, Lean was applied by Boeing to eliminate waste and make its products more cost-competitive. After implementing Lean, Boeing successfully cuts its defect costs by 75 percent, which resulted in a cost savings of about $\$ 655,000$ per aircraft (Ross, 2008). Moreover, after applying Lean in its manufacturing system the inventory level of DELL dropped by $50 \%$ and the time required to produce a PC was reduced, and as a result, DELL can guarantee that customers will receive their products one week after they order them (Chen \& Cox, 2012).

\subsection{Lean Manufacturing}

A manufacturing company is a commercial business that converts raw materials or components into finished products. These products are intended to meet the expectations and demands of customers. Lean manufacturing is a team-based systematic approach to identifying and eliminating wasteful or non-value-adding activities within the manufacturing environment. The essence of lean manufacturing is to compress the time from the receipt of a customer order all the way through to receipt of payment which will result in increased productivity, increased throughput, reduced costs, improved quality, and increased customer satisfaction (Rizzardo \& Brooks, 2008).

Lean manufacturing focuses on reorganizing the following processes Waste reduction, minimizing steps and thereby reducing costs. Though lean manufacturing is widely regarded as a business strategy, few researchers have concentrated on the validation of its positive link with business performance (Vinodh \& Joy, 2012). A report by Mekong Capital (2004) elaborates that since lean manufacturing eliminates many of the problems associated with poor production scheduling and line balancing, it is particularly appropriate for companies that do not have enterprise requirements planning system in place.

\subsection{Supplier Relationship Management (SRM)}

Supplier Relationship Management (or SRM) came into life in 1983 when McKinsey consultant Peter Kraljic called for corporate buyers to grow more proactive in supply management. He argued that buyers should look to understand their categories' risk and profitability impact upon a company and devise supplier management strategies that best meet this need. SRM plays a vital role in shaping the FP and involves managing all interactions with third party firms that supply goods and services to a firm in order to maximize the value of these interactions. In practice, SRM requires creating closer and more collaborative 
relationship with key supplier in order to reveal and realize new value and reduce risk of failure (Flynn et al., 2010).

To understand SRM on a deeper level, it's crucial that one knows and understand what Supply Chain Management (SCM) is and what it involves.

A supply chain is a network of facilities and distribution options that performs the functions of procurement of materials, transformation of these materials into intermediate and finished products, and the distribution of these finished products to customers (Ganeshan \& Harrison, 1999). SCM is a theory grounded in the field of logistics. Introduced by Houlihan (1984), it developed initially along the lines of physical distribution and transport using the technique of industrial dynamics based on the work of Forrester (Lamming, 1996: p. 2). Christopher (1998) simplifies that SCM is "the management of upstream and downstream relationships with suppliers and customers to deliver superior customer value at less cost to the supply chain as a whole".

SCM involves integration, co-ordination and collaboration across organizations and throughout the supply chain of such functions as distribution planning, demand forecasting, purchasing, requirement planning, production planning, warehousing, material handling, inventory, packaging, order processing, and transportation, etc.

From this we understand more clearly that SRM is essentially, the process for organizations to determine the supply categories that are important and creating the strategies that manage these items in an intelligent fashion. It is worth noting that SRM is not equivalent to collaborating with key strategic partners. This is a common misconception in procurement. Rather, it demands that buyers fundamentally shift their mindsets to understand the possibility of alternative partnership dynamics. SRM is a demanding process and few organizations are adept at deploying it. But, for those that can, they can create enormous value for their businesses. Through the study of SRM a lot of practices have evolved. Boer and Boer (2019) identified four aspects of SRM, namely sharing information, developing collaborative approaches, joint decision making, and system coupling with key suppliers. Duhaylongsod and De Giovanni (2019) highlighted a few activities that give meaning to SRM. They pointed that an organization must involve in sharing information with suppliers through a coordinated information system, working with key suppliers in product and process innovation, working with them for developing new technologies, and involving them in the implementation of firm's logistics network.

\subsection{Lean and SRM}

Lean includes a wide range of principles and tools with the goal of identifying and removing waste to increase process velocity. Put in plainer terms, Lean practices seek to maximize value to the customer or client, whilst minimizing waste of all kinds. Any activity that uses resource but does not create any additional value is a waste that should be removed. In brief, lean can be defined as 
achieving more outputs with fewer inputs.

After knowing what lean is, it still remains very critical to know how to become lean. This can be accomplished by a group of collaborative administrative practices called lean practices. These practices include but are not confined to SRM, constants progress, just-in-time (JIT), total quality management (TQM), work teams, employee involvement, and cellular manufacturing.

A lot of intellectual studies (Wickramasinghe \& Wickramasinghe 2017, Dave \& Sohani, 2019, Shah \& Ward, 2007, Browning \& Heath, 2009, Belekoukias et al., 2014; Sahoo \& Yadav, 2018) provide a presentation of the best commonly known lean practices in literature. Different studies (Nawanir et al., 2013, Wickramasinghe \& Wickramasinghe, 2017, Dave \& Sohani, 2019, Yang et al., 2011, Taj \& Morosan, 2011; Sangwa \& Sangwan, 2018) uphold the good impact of these lean practices on Firm Performance. But then, a study set of literature (Al-Tahat \& Bwaliez, 2015; Kim, 2015; Abushaikha et al., 2018) has focused on analyzing lean with other administrative practices.

Supplier relationship management (SRM) is an area of Supply Chain Management (SCM) which involves strategically planning and managing all relationships or associations with third party organizations that supply goods and/ or services to organizations (CIO Leadership, 2009). In practice, SRM involves creating mutual beneficial collaborative relationships with suppliers in order to uncover and realize new value and mitigate supply chain (Mettler \& Rohner, 2009).

Supplier relationships management is going to make or break your business. It is advisable to effectively manage them in order to maintain your costs and manage your assets. With the right strategy in place, transactional costs are lowered while still being able to expand your competitive advantage within your industry. It is therefore important to adopt the best practices which help in managing relationships.

This study combines lean and SRM to represent a lean-based SRM system. LSRM is a methodical advance that incorporates successful supplier relationship with lean practices to drive incompetence out of the firm. To implement LSRM, firms need to follow a set of LSRM practices. LSRM practices can be defined as a collection of SRM practices in a firm to increase its productive SCM. They can also be explained as a set of supplier-related activities that are focusing on removing waste by reducing records and improving quality in the supply chain. So far, a discussion on deciding the LSRM practices remains uncertain (Dave \& Sohani, 2019) as there is not at all a decided list of LSRM practices. As a result, a broad literature on countless publications has been examined again in order to compose a complete listing of the top LSRM practices. Four practices were established with the most generally used SRM practices in lean context, As follows: supply flexibility (SF), JIT delivery (JD), knowledge sharing (KS), and supplier partnership (SP). These practices with their representations are as follows: These concepts would be explained in the literature review section. 


\subsection{Firm Performance}

A measure of performance of a company that may not only depend on the efficiency of the company itself but also on the market where it operates. In the financial sector, it also known as financial stability or financial health. There are different financial measures that can be used in order to evaluate the performance of a company that uses subjective and objective measures. Some of the objective financial measures are: revenue, return on equity, return on assets, profit margin, sales growth, capital adequacy, liquidity ratio, and stock prices (Shariff, Peou, \& Ali, 2010). Subjective measures may include employee commitment and satisfaction, customer satisfaction and loyalty and minimal customer complaints help create sustainable shareholders value (Cumby \& Conrod, 2001).

\subsection{Hypothesis Development}

Lean supplier relationship management is a broad concept, and many studies have tried to digest and explore this concept using different research methods and analysis. This paper joins the assertion that the various LSRM practices has a positive relationship with each other as well as having a positive impact on the firm performance. Therefore this paper seeks to analyze the direct relationship the LSRM have with each other and also establishing the link it has with firm performance

\subsubsection{Supplier Flexibility}

In a supply Chain, the suppliers' flexibility is considered as a toll to cope with the environmental uncertainties. Flexible suppliers are capable of supplying or processing other jobs in addition to the one for which they are the original supplier. In other words, supplier flexibility refers to the ability of suppliers to manage production resources and uncertainty to enhance flexibility in meeting the variable demands of buyers. Flexibility is a reaction to dynamic environments (Giunipero et al., 2005; Upton, 1995; Vickery et al., 1999), and as such, is an important relational norm in inter-organizational relationships (Ivens, 2005). A flexible supplier can increase manufacturer's competitive advantage by improving response time to the ever-changing demands of customers. Suppliers have drawn the attention of many researchers recently.

Supplier flexibility has become an extremely important issue in today's rapidly changing markets, and due to the growing importance of purchasing as a means to improve the supply chain. Supply flexibility responds to the changing demands of a buyer in the areas of delivery, volume, and modification.

Studies have shown that selecting the suitable supplier with good SF helps in developing SP between the firm and its suppliers through evaluating suppliers' performance and their capability of providing innovations and co-designing products to meet customer needs.

An organization that coordinates with suppliers that have flexibility is likely to 
have delivery time advantage that is delivery reliability. Delivery reliability refers to the ability to deliver on time or before the promised scheduled due date (Handfield \& Pannesi, 1992). However, delivery dependability refers to the ability to deliver on time with accurate quantities and types of products needed (White, 1996). A supplier's delivery reliability and dependability enable the manufacturer to easily adapt to customer needs. If the supplier lacks the ability to accommodate rush orders and delivery on the promised due dates (Chan, 2003), it may create a negative customer value for the manufacturer.

A high degree of supply flexibility increases the performances of the firm in the sense that its suppliers are committed in providing quality products, working on time and other key objectives. In the end, most manufacturing organizations desire to achieve customer satisfaction because of the numerous benefits it brings to the organization.

From the above literature we can derive the following hypothesis

H1: SF has a positive effect on JD

$\mathrm{H} 2$ : SF has a positive effect on KS

H3: SF has a positive effect on SP

H4: SF has a positive effect on FP

\subsubsection{Just in Time Delivery (JD)}

Just-in-time, or JIT, is formally defined as "an approach to achieving excellence in a manufacturing company based on the continuing elimination of waste (waste being considered as those things which do not add value to the product)"

JIT more appropriately came to be viewed as a philosophy of management whose objective is the complete elimination of waste from a productive system.

Various elements such as preventive maintenance and frequent supplier deliveries are the techniques which allow progress to be made towards the waste elimination goal.

JIT requires considerably more than daily supplier deliveries to be effective. The entire organization must become involved in and committed to the process in order to promote continuous improvement. On this note, mangers prefer to choose suitable suppliers based on their past delivery services and performances. According to Barla 2003, JD has the tendency to facilitate a good relationship between the firm and its suppliers. Through JD, the firm shares information with its suppliers, and likewise hence this develops or evolves into a mutual and trusted long term relationship with suppliers (Singh \& Singh, 2015). In relation to firm performance, JD plays a vital role by enhancing the quality of goods and services to achieve efficiency in operations. JD has also been pointed out as an important factor for manufacturing companies to gain global competitiveness (Singh \& Garg, 2011).

From this we can deduce the following hypothesis

H5: JD positively affects knowledge sharing

H6: JD positively affects firm performance 


\subsubsection{Knowledge Sharing (KS)}

Knowledge sharing is defined as "processes that involve exchanging knowledge between individuals and groups" (Yu et al., 2010: p. 32). Also, it is "the provision of task, information and know-how to help others and to collaborate with others to solve problems, develop new ideas, or implement policies or procedures" (Wang \& Noe, 2010: p. 117). Liaw et al. (2008) opined that sharing knowledge is an important goal for organizations. All the individuals' experiences and knowledge can be transferred as an organizational asset with the help of technologies so that it is maintained as a resource for future learning.

Frappaolo (2006) claimed that knowledge sharing is about "how people share and use what they know". In addition, Tasmin and Woods (2007) asserted that knowledge sharing as a social system that supports collaboration and integration which is normally facilitated by technology. Knowledge sharing is very important to create flexible manufacturing and products developments. Effective sharing of knowledge enables supply chains for reducing time to market and develop process modularity. Knowledge in a supply chain allows partners to integrate their knowledge to identify opportunities in the market and develop a potential competitive advantage (Gavirneni et al., 1999, Sambamurthy et al., 2003). The strong bond formed through knowledge sharing tend to improve firm performance because activities are now coordinated effectively (Lin et al., 2005).

The following hypothesis can be developed from the above literature.

H7: KS positively affects firm performance

\subsubsection{Supplier Partnership (SP)}

Partnership is a term that carries rich positive connotations in management. In purchasing context it is widely used and means and apparently means a modern view of supplier relationships. Partnering is defined as a continuing relationship between a buying firm and supplying firm, involving a commitment over an extended period of time, an exchange of information and acknowledgement of the risk and rewards of the relationship. Supplier partnership is defined as a long term strategic coalition of two or more firms in a supply chain to facilitate joint effort and collaboration in one or more core value creating activities such as research, product development, manufacturing, marketing, sales and distribution, with the objective of increasing benefits to all partners (Maheshwari et al., 2006; Li et al., 2006).

Supplier partnership in SCM has been reported to yield organization-specific benefits in terms of financial performance (Tsai, 2007). Vereecke \& Muylee (2006) highlighted that strategic partnerships between suppliers and manufacturers may have a significant impact on supply chain performance. Furthermore, prior studies have indicated that the various components of SCM (such as SP) have an impact on various aspects of competitive advantage (such as price/cost) (Li et al., 2006). In addition it is also known that supplier partnership helps cus- 
tomers' needs to be met.

H8: SP positively affects Firm Performance.

\section{Research Methodology}

Our main interest is discovering how LSRM practices affect firm performance among manufacturing companies in Ghana. This study is mainly a cross-sectional study which intends to explore the relationship between LSRM practices and firm performance in manufacturing companies in Ghana. The research questionnaire design, research model and sample size are presented in the next subsections.

\subsection{Sample Size Determination}

A close-ended questionnaire was used to collect data for our study. A simple random technique was also used in selecting the respondents (Managers and Supervisors). Yamane (1967) devise a formula for determining sample size from a population under study, we used this formula to determine our sample size from a population of 500 managers and supervisors from different manufacturing companies based in Accra. A total of 222 questionnaires were distributed and 200 were received and used for further analysis. The effective recovery rate of questionnaire was approximately $90.1 \%$.

$$
\begin{gathered}
n=\frac{N}{1+N(e)^{2}} \\
n=\frac{500}{1+500 \times(0.05)}=222.222 \sim 222
\end{gathered}
$$

where:

$$
\begin{aligned}
& n=\text { sample size } \\
& N=\text { population of the study } \\
& e=\text { error parameter }(5 \%), 95 \% \text { confidence level }
\end{aligned}
$$

\subsection{Research Model}

To examine the relationship between LSRM practices and Firm Performance (FP), we proposed a research model shown in Figure 1. The LSRM practices proposed in the model are SF, JD, KS and SP. Furthermore, the model proposes that the LSRM practices are the endogenous variables and Firm Performance (FP) is the exogenous variable. As seen in Figure 1, there are arrows that connect the LSRM practices to FP and amongst themselves. This seeks to explore the relationship between each of the LSRM practices and FP. The relationships amongst LSRM practices and between FP will be estimated using structural approach by building a structural equation model.

\subsection{Questionnaire Design and Measurement}

Data for the study was collected through a closed-ended questionnaire survey. A 


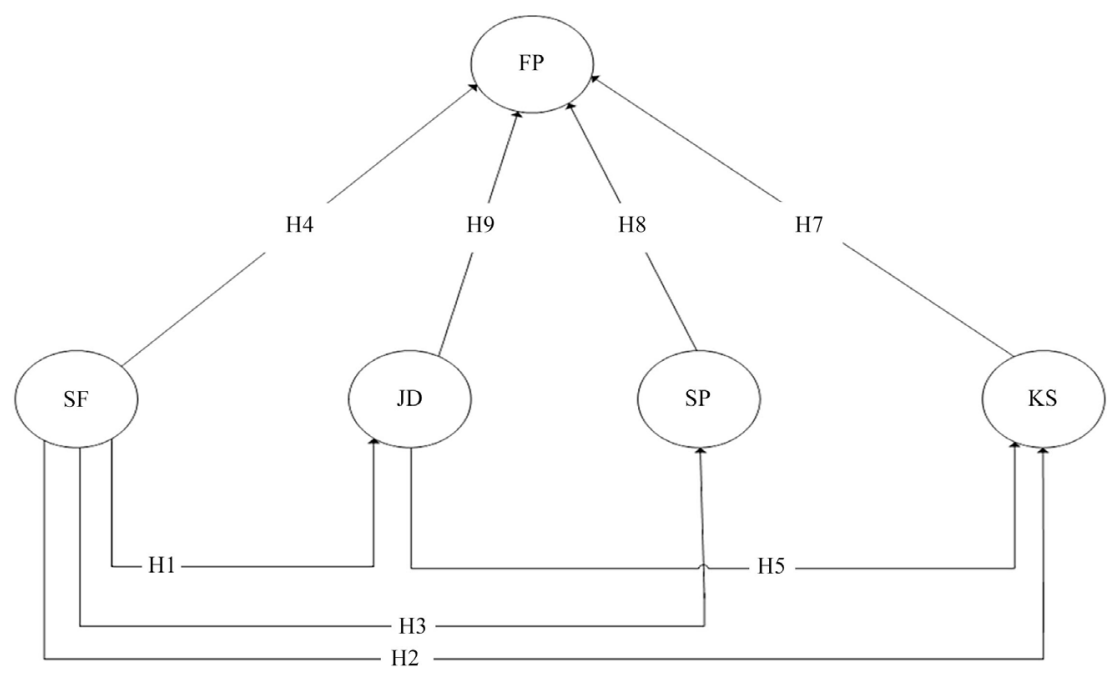

Figure 1. Research model.

total of 200 questionnaires were obtained from the 222 questionnaires distributed to managers and supervisors of the manufacturing companies based in Accra, indicating a response rate of $91 \%$. The questionnaire employed for this study was adapted from (Bwaliez \& Abushaikha, 2019). The questionnaire was sectioned in three (3) parts. The first part of the questionnaire required the respondents' demographic information such as age, gender, level of education and length of service.

\subsection{LSRM Practices Constructs}

The second part of the questionnaire consists of the LSRM practices as proposed in the research model. The LSRM practices was also subdivided into SF, SP, JD and KS constructs containing 7 items, 9 items, 6 items and 10 items respectively. The respondents (managers and supervisors) were required to evaluate how the LSRM practices are integrated in their business activities on a five-point Likert scale where 1 = "Strongly disagree", 2 = "Disagree", 3 = "Agree", 4 = "Generally Agree" and 5 = "Strongly agree". The measurement items under LSRM practices were adapted from (Kar \& Pani, 2014; Ekici, 2013; Marodin et al., 2017; Wu, 2003; Kisperska-Moron \& De Haan, 2011; Samawi et al., 2019; Jajja et al., 2017; Liu et al., 2012; Minh et al., 2019; So \& Sun, 2010; De Araújo et al., 2015; Qrunfleh et al., 2012; Womack et al., 1990) and modified to suit our study.

\subsection{Firm Performance (FP) Construct}

The third part of the questionnaire consists of the measurement items and scale for firm performance. Respondents were required to evaluate their respective firm performance in the last three (3) years of business on a five-point Likert scale ranging from 1 = "Strong disagree", 2 = "Disagree", 3 = "Agree", 4 = "Generally Agree" and $5=$ "Strongly agree". The measurement items of firm performance included both financial and non-financial indicators as recommended by 
Cao \& Zhang (2011). Examples of items includes; revenue growth, overall competitive advantage, productivity, overall growth, customer satisfaction. 8 measurement indicators were used for FP and adapted from (Kafetzopoulos et al., 2019; Sezhiyan \& Nambirajan, 2010; Forkmann et al., 2016) and modified to fit our study.

\section{Results and Discussion}

Data from our study was analyzed using Statistical Package for Social Sciences (IBM SPSS version 25) and Analysis of Moment (IBM AMOS version 24).We performed a descriptive analysis to understand more about the demographic characteristics of respondents under study. A Structural Equation Modeling (SEM) analysis was also performed to evaluate the relationship between the latent and manifest variables presented in our research model (Figure 1). SEM is the most prevalent statistical analysis and methodology used in supply chain research (Kumar \& Nambirajan, 2013) and it involves modeling of an event by considering both the latent and manifest variables that describes the event (Ganiyu et al., 2020). The analyses consist of descriptive characteristics of respondents, fitting indices of model parameters, validity and reliability analyses, Multicollinearity and autocorrelation and hypothesis testing. The results are presented in the subsections below.

\subsection{Descriptive Characteristics}

The descriptive statistics in Table 1 revealed that $56 \%$ of our respondents were males while $44 \%$ were females. Result also indicated that $4 \%$ of our respondents were below the age of $21,45.50 \%$ between the ages of $21-30,42 \%$ between the ages of $31-40$ and $8.50 \%$ are above 41 years. Less than $1 \%(0.50 \%)$ of our respondents had primary education while $1.50 \%$ and $98 \%$ had secondary and tertiary education respectively. The tertiary education consists of Technical training, Vocational training, and University. $36 \%$ of our respondents have worked in their current position for 1 - 3 years while $50 \%$ and $14 \%$ have worked for $4-7$ years and above 8 years respectively.

\subsection{Structural Model}

Table 2 shows the results for the structural model. The standardized factor loadings are all statistically significant at the 95\% confidence interval with P-values less than $0.05(P<0.05)$ and T-values greater than $1.96\left(t_{\text {cal }}>t_{\text {critical }}\right)$. Factor loadings of at least 0.60 are considered as reliable indicators or satisfactory items (Field, 2009; Hair Jr. et al., 2006). Standardized factor loadings presented in Table 2 are all greater than the minimum threshold recommended indicating that our items load satisfactorily.

\subsection{Construct Validity and Reliability}

The construct validity of our structural model was examined by using Bagozzi \& 
Yi (1998) Composite Reliability (CR) index and Fornell \& Lacker (1981) Average Variance Extracted (AVE). Construct validity is the national-empirical procedure for examining the psychological attributes of a measure or scale (Cohen \& Swerdlik, 2005). It is a subset of Convergent validity and Discriminant validity (Hubley \& Zumbo, 1996; Gregory, 2007; Campbell \& Fiske, 1959).

Table 1. Descriptive characteristics of respondents.

\begin{tabular}{|c|c|c|c|c|}
\hline Demographic Characteristic & Frequency & Percent & Valid Percent & Cumulative Percent \\
\hline \multicolumn{5}{|l|}{ Gender } \\
\hline Male & 112 & 56.00 & 56.00 & 56.00 \\
\hline Female & 88 & 44.00 & 44.00 & 100.00 \\
\hline Total & 200 & 100.00 & 100.00 & \\
\hline \multicolumn{5}{|l|}{ Educational Level } \\
\hline Primary & 1 & 0.50 & 0.50 & 0.50 \\
\hline Secondary & 3 & 1.50 & 1.50 & 2.00 \\
\hline Tertiary & 196 & 98.00 & 98.00 & 100.00 \\
\hline Total & 200 & 100.00 & 100.00 & \\
\hline \multicolumn{5}{|l|}{ Age } \\
\hline Below 21 & 8 & 4.00 & 4.00 & 4.00 \\
\hline $21-30$ & 91 & 45.50 & 45.50 & 49.50 \\
\hline $31-40$ & 84 & 42.00 & 42.50 & 91.5 \\
\hline Above 41 & 17 & 8.50 & 8.50 & 100.00 \\
\hline Total & 200 & 100.00 & 100.00 & \\
\hline \multicolumn{5}{|l|}{ Length of Service (years) } \\
\hline $1-3$ & 72 & 36.00 & 36.00 & 36.00 \\
\hline $4-7$ & 100 & 50.00 & 50.00 & 86.00 \\
\hline Above 8 & 28 & 14.00 & 14.00 & 100.00 \\
\hline Total & & 100.00 & 100.00 & \\
\hline
\end{tabular}

Table 2. Results of structural model.

\begin{tabular}{cccccccc}
\hline $\begin{array}{c}\text { Latent } \\
\text { Variable }\end{array}$ & Items & Standardized loading & t- value & $\boldsymbol{P}$-value & AVE & CR $\begin{array}{c}\text { Cronbach's } \\
\text { Alpha }\end{array}$ \\
\hline & FP1 & 0.64 & 8.03 & $* * *$ & & & \\
& FP2 & 0.87 & 7.350 & $* * *$ & & & \\
& FP3 & 0.64 & a & a & & & \\
FP & FP4 & 0.85 & 8.02 & $* * *$ & 0.56 & 0.91 & 0.84 \\
& FP5 & 0.65 & 8.15 & $* * *$ & & & \\
& FP6 & 0.71 & 7.29 & $* * *$ & & & \\
\hline
\end{tabular}




\section{Continued}

\begin{tabular}{|c|c|c|c|c|c|c|c|}
\hline & FP8 & 0.65 & 8.12 & $* * *$ & & & \\
\hline & FP9 & 0.92 & 7.81 & $* * *$ & & & \\
\hline & JD1 & 0.89 & 6.73 & $* * *$ & & & \\
\hline & JD2 & 0.64 & 7.11 & $* * *$ & & & \\
\hline \multirow[t]{8}{*}{ JD } & JD3 & 0.62 & 7.02 & $* * *$ & 0.55 & 0.88 & 0.78 \\
\hline & JD4 & 0.60 & a & $\mathrm{a}$ & & & \\
\hline & JD5 & 0.63 & 7.02 & $* * *$ & & & \\
\hline & JD6 & 0.96 & 6.52 & $* * *$ & & & \\
\hline & SP2 & 0.86 & 7.08 & $* * *$ & & & \\
\hline & SP3 & 0.60 & 7.44 & $* * *$ & & & \\
\hline & SP4 & 0.87 & 7.08 & $* * *$ & & & \\
\hline & SP5 & 0.58 & $\mathrm{a}$ & $\mathrm{a}$ & & & \\
\hline \multirow[t]{8}{*}{ SP } & SP6 & 0.88 & 7.01 & $* * *$ & 0.61 & 0.93 & 0.82 \\
\hline & SP7 & 0.61 & 7.49 & $* * *$ & & & \\
\hline & SP8 & 0.76 & 6.97 & $* * *$ & & & \\
\hline & SP9 & 0.99 & 7.35 & $* * *$ & & & \\
\hline & SP10 & 0.65 & 7.21 & $* * *$ & & & \\
\hline & SF1 & 0.92 & 7.38 & $* * *$ & & & \\
\hline & SF2 & 0.65 & 7.32 & $* * *$ & & & \\
\hline & SF3 & 0.64 & 7.33 & $* * *$ & & & \\
\hline \multirow[t]{8}{*}{ SF } & SF4 & 0.81 & 6.82 & $* * *$ & 0.51 & 0.88 & 0.80 \\
\hline & SF5 & 0.60 & 7.81 & $* * *$ & & & \\
\hline & SF6 & 0.70 & $\mathrm{a}$ & $\mathrm{a}$ & & & \\
\hline & SF9 & 0.60 & 6.50 & $* * *$ & & & \\
\hline & KS1 & 0.85 & 7.42 & $* * *$ & & & \\
\hline & KS2 & 0.79 & 7.45 & $* * *$ & & & \\
\hline & KS3 & 0.66 & 7.03 & $* * *$ & & & \\
\hline & KS4 & 0.66 & a & $\mathrm{a}$ & & & \\
\hline \multirow[t]{6}{*}{$\mathrm{KS}$} & KS5 & 0.64 & 7.95 & $* * *$ & 0.54 & 0.92 & 0.85 \\
\hline & KS6 & 0.65 & 8.09 & $* * *$ & & & \\
\hline & KS7 & 0.80 & 7.55 & $* * *$ & & & \\
\hline & KS8 & 0.60 & 7.51 & $* * *$ & & & \\
\hline & KS9 & 0.64 & 7.92 & $* * *$ & & & \\
\hline & KS10 & 0.96 & 7.02 & $* * *$ & & & \\
\hline
\end{tabular}

${ }^{* * *} P$-value $<0.001$ (2-tailed) a: Unitized parameter. 


\section{- Convergent validity}

The main idea of convergent validity is that related construct's tests should be highly correlated. That's it seeks to reveal convergence among similar measures (Chin \& Yao, 2014). A minimum AVE value of 0.50 is required to achieve convergent validity. Result in Table 2 shows that convergent validity was achieved since all AVE values are greater than the minimum 0.50 value.

- Discriminant validity

Discriminant validity is established by evidence that measures of construct that theoretically should not be highly related to each other are truly not found to be highly related to each other. That's it seeks to discriminate between dissimilar measures (Hubley, 2014). According to Fornell and Lacker (1981), if the square root of the AVE of each latent construct is greater than the correlation coefficients between that latent construct and other latent constructs in the measurement model, then the model satisfies the discriminant validity criterion. Result in Table 3 indicates that the square root of the AVE for each of the latent construct is greater than the inter-correlations between the latent constructs. Therefore discriminant validity was also achieved.

Cronbach's alpha and Composite reliability (Construct liability) statistic both measures the internal consistency in scale items (Netemeyer, 2003; Spiliotopoulou, 2009). This test statistics measure the reliability of the questionnaire used in this study. Though Composite reliability is a less bias estimate of internal consistency, Cronbach's alpha is the most preferred (Devon et al., 2007). (Fornell \& Lacker, 1981; Bagozzi \& Yi, 1998) recommended a minimum Composite reliability value of 0.60 and Bland \& Altman (1997) recommended a minimum Cronbach's value of 0.70 for good or acceptable reliabilities. Result in Table 2 indicates that the estimated Cronbach's alpha and Composite reliability values are above the minimum threshold to achieve construct liability, therefore the reliability of our constructs was achieved.

\subsection{Model Fit}

Model fitness refers to the extent to which the SEM matches the observed data. The evaluation of model fit is to confirm the theoretical model by method of fitting parameters (Ganiyu et al., 2020). For this study, the following fitting indices were employed to measure the model fitness: Chi-square ratio $\left(\chi^{2}\right.$-ratio), Root Mean Square Error of Approximation (RMSEA), Comparative Fit Index (CFI), Tucker-Lewis Index (TLI), Goodness of Fit Index (GFI), Normed Fit Index (NFI) and Standardized Root Mean Square Residual (SRMR). Kline (2005) suggests that a minimum of the following indices: the model $\chi^{2}$, RMSEA, CFI, SRMR, should be reported for model fit.

(Hooper et al., 2008; Kline, 2005; Steiger, 2007; Wen et al., 2004; Burnham \& Anderson, 2002; Hoyle \& Panter, 1995) recommended the cut-off criteria for the fitting indices. They assert that, a Chi-square ratio $\left(\chi^{2}\right.$-ratio) less than 3 indicates 
Table 3. Correlation matrix.

\begin{tabular}{cccccccc}
\hline \multirow{2}{*}{ Variable } & \multicolumn{7}{c}{ Correlation matrix } \\
\cline { 2 - 7 } & Mean & Std. Dev & 1 & 2 & 3 & 4 & 5 \\
\hline FP & 28.82 & 4.42 & $\mathbf{0 . 7 4 8}$ & & & & \\
SF & 24.73 & 3.59 & $0.73^{* *}$ & $\mathbf{0 . 7 1 4}$ & & & \\
JD & 20.82 & 4.72 & $0.66^{* *}$ & $0.66^{* *}$ & $\mathbf{0 . 7 4 2}$ & & \\
KS & 36.29 & 5.09 & $0.65^{* *}$ & $0.59^{* *}$ & $0.61^{* *}$ & $\mathbf{0 . 7 3 5}$ & \\
SP & 33.06 & 5.70 & $0.68^{* *}$ & $0.57^{* *}$ & $0.61^{* *}$ & $0.76^{* *}$ & $\mathbf{0}$ \\
\hline
\end{tabular}

*** Correlation is significant at the 0.01 (2-tailed); Square root of AVEs are presented in the diagonals.

a good and acceptable model; however, it is not always regarded as a clear assessment tool for model fit (Bwaliez \& Abushaikha, 2019). TLI is recommended to be greater than 0.95 ( $\mathrm{TLI} \geq 0.95$ ), however TLI $>0.90$ indicates an acceptable model fit. CFI is recommended to be greater than 0.90 (CFI > 0.90) for a good model fit. Both RMSEA and SRMR are also recommended to be less than 0.05 (RMSEA, SRMR < 0.05) for a satisfactory model fit and less than 0.08 (RMSEA, SRMR < 0.08) for an acceptable model fit. GFI and NFI are mandated to be greater than 0.95 (GFI, NFI > 0.95) for a satisfactory model fit. Result in Table 4 indicates that the fitting indices for each of the latent construct have been achieved and the overall structural model fitness has also been achieved.

\subsection{Multicollinearity and Autocorrelation}

Multicollinearity generally occurs when high correlations exist between two or more predictor variables. It indicates the extent to which items in a questionnaire measure the same entity (Haier Jr. et al., 2014). Multicollinearity of the dataset is measured by Tolerance value, Variance-Inflation-Factor (VIF) and the coefficient of correlations. According to Yoo et al. (2014), a correlation coefficient greater than $0.80(\rho>0.80)$ indicates the presence of multicollinearity. A tolerance value less than 0.10 indicate the presence of multicollinearity (Daoud, 2017) and an acceptable minimum of 5 recommended for VIF value (Ringle et al., 2015). Durbin-Watson test examines the presence of serial correlation or autocorrelation in the dataset. Values ranging from 1 - 3 are recommended (Field, 2009). The coefficients of correlations in Table 5 indicate moderate relationships between the variables and are all less than the 0.80 threshold, implying no multicollinearity in the dataset. Table 6 indicates that, the desired estimates for Tolerance, VIF and Durbin-Watson were all achieved, further indicating no multicollinearity and autocorrelation in our dataset.

\subsection{Hypothesis Testing}

The results for testing the hypotheses formulated in this study are presented in Table 6. 
Table 4. Fitting indices for individual constructs and overall structural model.

\begin{tabular}{ccccccccc}
\hline \multirow{2}{*}{ Model } & \multirow{7}{*}{ Variables } & \multicolumn{7}{c}{ Fitting Parameters } \\
\cline { 3 - 8 } & & fP $/$ df & RMSEA & CFI & TLI & GFI & NFI & SRMR \\
\hline \multirow{2}{*}{ Individual } & SF & 2.450 & 0.042 & 0.923 & 0.869 & 0.954 & 0.901 & 0.042 \\
Construct & JD & 2.096 & 0.074 & 0.961 & 0.935 & 0.969 & 0.951 & 0.032 \\
& KS & 1.602 & 0.055 & 0.962 & 0.951 & 0.948 & 0.955 & 0.033 \\
& SP & 1.679 & 0.058 & 0.950 & 0.936 & 0.958 & 0.987 & 0.033 \\
Overall & & & & & & & & \\
Structural & & 1.278 & 0.037 & 0.929 & 0.956 & 0.952 & 0.957 & 0.039 \\
model & & & & & & & & \\
\hline
\end{tabular}

Table 5. Collinearity and autocorrelation statistics.

\begin{tabular}{cccc}
\hline Variable & Tolerance & VIF & Durbin-Watson \\
\hline SF & 0.499 & 2.002 & \\
JD & 0.467 & 2.142 & 2.180 \\
KS & 0.387 & 2.582 & \\
SP & 0.380 & 2.630 \\
\hline
\end{tabular}

Table 6. Hypothesis testing and decision.

\begin{tabular}{ccccccc}
\hline Hypothesis & Relationship & $\begin{array}{c}\text { Path } \\
\text { coefficient }\end{array}$ & SE & t-value & p-value & $\begin{array}{c}\text { Hypothesis } \\
\text { Decision }\end{array}$ \\
\hline H1 & SF $\rightarrow$ JD & 0.82 & 0.12 & 6.78 & $* * *$ & Supported \\
H3 & SF $\rightarrow$ KS & 0.60 & 0.18 & 3.40 & $* * *$ & Supported \\
H3 & SF $\rightarrow$ SP & 0.73 & 0.11 & 6.70 & $* * *$ & Supported \\
H4 & SF $\rightarrow$ FP & 0.64 & 0.21 & 3.06 & $0.002^{* * *}$ & Supported \\
H5 & JD $\rightarrow$ KS & 0.68 & 0.17 & 3.55 & $0.023^{* * *}$ & Supported \\
H6 & JD $\rightarrow$ FP & 0.42 & 0.18 & 2.20 & $0.015^{* * *}$ & Supported \\
H7 & KS $\rightarrow$ FP & 0.10 & 0.19 & 1.51 & 0.067 & Not Supported \\
H8 & SP $\rightarrow$ FP & 0.45 & 0.20 & 2.23 & $0.026^{* * *}$ & Supported \\
\hline
\end{tabular}

$* * *$ Statistically significant at the 0.05 level $(P<0.05)$.

H1: Supplier Flexibility (SF) has a positive effect on Just-In Time Delivery (JD)

The estimated path coefficient from SF to JD is 0.82 . This path coefficient is statistically significant at the $95 \%$ confidence interval and its corresponding T-value is also statistically different from zero with a value of 6.78. This significant association confirms the positive impact of SF on JD. Chirra \& Kumar (2018) have indicated the role supply flexibility plays in areas of delivery, volume and modification implying that, enabling supply chain flexibility will enhance 
the delivery capability of manufacturing firms in Ghana. It is evidence from the results that, manufacturing firms that place higher priority in coordinating with suppliers to create efficient, effective and flexible supply networks are likely to have delivery on time advantage. Consequently, hypothesis 1 was supported and we conclude that, SF has a positive effect on JD.

H2: Supplier Flexibility (SF) has a positive effect on Knowledge Sharing (KS)

The estimated path coefficient from SF to KS is 0.60 . The strength of the association is positive and statistically significant at the $95 \%$ confidence interval. The T-value for the estimated path coefficient is 3.40 , indicating a statistical significance. Knowledge sharing plays a significant role in driving the flexibility in supply chain networks of businesses. Organizations or business firms that develop an effective communication and sharing of business process information are more likely to have efficient, effective supplier flexibility in its supply chain network. Several companies have put in place measures to ensure flexibility and effectiveness in their business activities by sharing information on production times, inventory and other business processes with suppliers to ensure timely productions. The significant relationship between SF and KS reveals that, SF has a positive effect on KS. Therefore we accept our hypothesis 2 and conclude that Supplier Flexibility (SF) has a positive effect on Knowledge Sharing (KS).

H3: Supplier Flexibility (SF) has a positive effect on Supplier Partnership (SP)

The extent of partnership between manufacturing firms and their supplies defines the degree of flexibility in production and logistics processes. Both SF and $\mathrm{SP}$ are critical contributors to the performance of manufacturing companies. The estimated path coefficient from SF to SP is positive and statistically significant at the $95 \%$ confidence level $(\beta=0.73, P<0.05)$. The corresponding T-value for the path coefficient is 6.70 , indicating statistical significance. Manufacturing firms that develop and implement measures to ensure flexibility in their supply chains are more likely to have a long-term supply partnership with other firms and their suppliers. Some researchers (So \& Sun, 2010; Joshi et al., 2017) have indicated the importance that manufacturing firms attached to selecting suitable suppliers with efficient and effective SF to enhance and solidify business-to-supplier partnerships. This strategically put firms at competitive advantages against business rivals. Based on the result in Table 6, we accept our hypothesis 3 and conclude that, Supplier Flexibility (SF) has a positive effect on Supply Partnership (SP).

H4: Supplier Flexibility (SF) has a positive effect on Firm Performance (FP) Most manufacturing firms invest in developing measures to ensure flexibility in their supply chain activities. It is evidence that, firms with higher extents of supply flexibility are more likely to have an increase in firm performance since suppliers are committed in providing good quality raw materials, working on time, JIT delivery. Result in Table 1 indicates a positive significant effect of SF on FP with an estimated path coefficient of 0.64 . The corresponding T-value is also significant with an estimate of 3.06. This indicates that, as supplier activities 
tend to be more efficient, effective and flexible, it's likely to increase the performance of the firm. Consequently, we accept our hypothesis 4 and conclude that Supplier Flexibility (SF) has a positive effect on Firm Performance (FP).

H5: Just-In-Time Delivery (JD) positively affects Knowledge Sharing (KS)

Most manufacturing companies pay critical attention to their delivery systems. Having an efficient and effective delivery system can enhance firm performance (Singh \& Garg, 2011). The flow of information and knowledge must be efficient in the entire business process of companies to ensure quicker delivery times. Business firms with adequate information or knowledge sharing platforms are more likely to achieve delivery time advantage since there is an effective communication between them and their suppliers. Result in Table 6 shows a significant positive effect of Just-In-Time Delivery (JD) on Knowledge Sharing (KS) $(\beta=0.68, P<0.05)$. This indicates the need of companies to share information with their suppliers to achieve delivery time advantage. Therefore we accept our hypothesis that JD positively affects KS.

H6: Just-In-Time Delivery (JD) positively affects Firm Performance (FP)

Just-In-Time delivery (JD) as widely used in supply chain management is intended to synchronize orders from customers to suppliers to ensure efficient and timely supply of products to customers. JD has the tendency to enhance firm performance and global competitiveness (Singh \& Garg, 2011). JD contribute to performance of manufacturing companies by enhancing the quality of goods and ensuring that the right quantity of goods are sent to the right location at the right time creating efficiency and effectiveness in operations. This shows the vital role JD plays in enhancing the performance of manufacturing firms. Results in Table 6 indicates that, JD positively affects FP $(\beta=0.42, P<0.05)$. The strength of the effect and its corresponding T-value (2.20) is statistically significant at the 95\% confidence interval. Thus, we accept our hypothesis 6 and conclude that JD positively affects FP.

H7: Knowledge Sharing (KS) positively affects Firm Performance (FP). The estimated path coefficient from Knowledge Sharing (KS) to Firm Performance (FP) is 0.10 . The strength of the relationship is statistically non-significant at the 95\% confidence level $(P>0.05)$. The corresponding T-value is 1.51 which is less than the critical value of 1.96 , indicating non-significance. This means that, KS does not have a direct significant effect on the performance of manufacturing companies in Ghana; however the mediating impact of JD between KS and FP is positive. Though KS may not have a direct significant positive effect on FP, it has a significant positive effect on JD which in turn has a positive effect on FP. This reveals the mediating effect of JD on KS and FP. The non-significant impact of KS on FP can be attributed to the fact that most business managers in Ghana do not reveal all information about their business processes to their suppliers (Dey, 2016), most of these companies fear that their business process information may be made known to their business rivals. This result opposes the findings of (Lin et al., 2005; Liaw et al., 2008; Sambamurthy et al., 2003; Bwaliez \& Abushaikha, 
2019) who revealed the significant positive effect of KS on FP. Thus based on the result in Table 6, we fail to accept our hypothesis 7 and conclude that there is a non-significant effect of Knowledge Sharing (KS) on Firm Performance (FP).

H8: Supplier Partnership (SP) positively affects Firm Performance (FP)

Result in Table 6 indicates a significant positive effect of Supplier Partnership (SP) on Firm Performance (FP). The path coefficient and the T-value are statistically significant at the $95 \%$ confidence intervals. Supplier Partnership (SP) plays an important role in enhancing Supplier Flexibility (SF) and Just-In-Time Delivery (JD). Partnership between firms and their suppliers ensures adequate circulation of information and knowledge within the business process, incorporating flexibility and quicker delivery times. (Tsai, 2007; Vereecke \& Muylee, 2006; Li et al., 2006) have indicated the significant impact of SP on firm performance. This means that manufacturing companies who partners with their supplier are more likely to enhance their performance since supplier partnership incorporates flexibility in supply activities. Thus, we accept our hypothesis 8 and conclude that Supplier Partnership (SP) positively affects Firm Performance (FP).

\section{Conclusion}

This research was done to understand buyer-supplier relationship and its efficiency on firm's performance and to also examine the relationship between LSRM practices and their effect on firm's performance. The study makes use of the principles of SRM and the practices of lean to establish a lean based SRM structure. With LSRM, the central firm works together with its supplier to lower cost and waste by pulling what is more necessary. LSRM can be attained through a set of practices that are focusing on removing waste by cutting down inventory and enhancing quality in the supply chain. From the literature review, this research considered JD, SP, SF and KS as the main LSRM practices. The research addresses the following two objectives: 1) Bringing together SRM and lean to develop an analysis instrument for measuring LSRM practices, and 2) To know the relationship between LSRM practices and firms performance. With the effect of practices on each other, the outcome gives fit evidence that the considered LSRM practices affect each other positively and they have a positive and significant effect on the performance of Ghana's manufacturing companies. That means all of the LSRM practices are very important expect for knowledge sharing (KS) on firms performance; the non-significant impact of KS on FP can be attributed to the fact that most business managers in Ghana do not reveal all information about their business processes to their suppliers (Dey, 2016); most of these companies fear that their business process information may be made known to their business rivals. SF practice has the highest impact on firm's performance, followed by JD practice, then SP practice, and KS practice. And also more focus should be given to SF and JD because of their high impact on firm performance. The findings of this research can act as a guide for LSRM practices 
in Ghana's manufacturing companies and serve as reference for future research. The research is important for Ghana's manufacturing companies to improve their performance and productivity. The lean concept does not only apply to manufacturing companies, but also, these companies operating in other sectors can fully explore lean as a method to improve their overall performance.

\section{Recommendation}

The benefits of lean supplier relationship management are undebatable. Companies like Boeing and DELL have undoubtedly reaped the full benefits of the lean program. However, today managers should pay critical attention to the challenges of implementing lean.

Implementing lean may not be easy as it sounds and this process might be considered a risky one. There are key things managers should not when they decide to introduce lean into the organization. One key thing to note about lean is that lean addresses how the people work and not necessarily how people think. This makes the lean process a technical one and managers need to skillfully incorporate the lean process. Another important point managers need to consider is the key objective of lean, because it might serve as a hindrance in the successful implantation of lean. One key objective of lean is to push responsibility far down the organizational ladder. This objective might lead to stressful outcomes, because people who did not have any responsibility might be given one and they might have its difficulty at the start. Management should therefore take this challenge into consideration when implementing lean.

The third crucial key thing, managers should pay attention to is customer intimacy and customer loyalty. Customer intimacy and customer loyalty are the base of LSRM to gain extra profit in the manufacturing sector, which means firms should focus on supplier's integration, just in time delivery, supplier partnership etc. A firm's ability to quickly respond to customers' request for proposal and requests for change is a plus and this can be achieved by involving the appropriate technical and management skills at the various channels.

\section{Limitations and Future Research Directions}

It is imperative for researchers to include their research limitations to serve as guidelines for future research directions. Although this research has attained some significant conclusions and insights related to the effects of LSRM practices on firm performance, it has limitations that can be addressed in future studies. This study was limited to one aspect of SCM (LSRM) which consists of four constructs: Supplier Partnership (SP), Supplier Flexibility (SF), Knowledge Sharing (KS) and Just-In-Time Delivery (JD) and Firm Performance. Future studies may explore other aspects of SCM such as transportation, Warehousing, Customer relationship management and Human resource management. It is further worth noting that this study was based on 200 manufacturing companies in Accra, Ghana, thus limiting the generalization of the findings. Future studies 
may expand the coverage area and sample size to make more generalized conclusions.

\section{Conflicts of Interest}

The authors declare no conflicts of interest regarding the publication of this paper.

\section{References}

Abushaikha, I., Salhieh, L., \& Towers, N. (2018). Improving Distribution and Business Performance through Lean Warehousing. International Journal of Retail \& Distribution Management, 46, 780-800. https://doi.org/10.1108/IJRDM-03-2018-0059

Al-Tahat, M. D., \& Bwaliez, O. M. (2015). Lean-Based Workforce Management in Jordanian Manufacturing Firms. International Journal of Lean Enterprise Research, 1, 284-316. https://doi.org/10.1504/IJLER.2015.071744

Aziz, R., \& Hafez, S. (2013). Applying Lean Thinking in Construction and Performance Improvement. Alexandria Engineering Journal, 52, 679-695.

https://doi.org/10.1016/j.aej.2013.04.008

Bagozzi, R. P., \& Yi, Y. (1998). On the Evaluation of Structure Equation Models. Journal of the Academy of Marketing Science, 16, 76-94.

Balle, F., et al. (2005). Feel the Force of Flexible Manpower. IET Manufacturing Engineer, 84, 20. https://doi.org/10.1049/me:20050603

Belekoukias, I., Garza-Reyes, J. A., \& Kumar, V. (2014). The Impact of Lean Methods and Tools on the Operational Performance of Manufacturing Organizations. International Journal of Production Research, 52, 5346-5366. https://doi.org/10.1080/00207543.2014.903348

Bland, J. M., \& Altman, D. G. (1997). Statistics Notes: Cronbach’s Alpha. BMJ, 314, 572. https://doi.org/10.1136/bmj.314.7080.572

Boer, H., \& Boer, H. (2019). Design-for-Variety and Operational Performance: The Mediating Role of Internal, Supplier, and Customer Integration. Journal of Manufacturing Technology Management, 30, 438-461. https://doi.org/10.1108/JMTM-03-2018-0065

Browning, T. R., \& Heath, R. D. (2009). Reconceptualizing the Effects of Lean on Production Costs with Evidence from the F-22 Program. Journal of Operations Management, 27, 23-44. https://doi.org/10.1016/j.jom.2008.03.009

Burnham, K. P., \& Anderson, D. R. (2002). Model Selection and Inference: A Practical Information-Theoretical Approach (2nd ed.). New York: Springer

Bwaliez, O. M., \& Abushaikha, I. (2019). Integrating the SRM and Lean Paradigms: The Constructs and Measurements. Theoretical Economics Letters, 9, 2371-2396. https://doi.org/10.4236/tel.2019.97151

Campbell, D. T., \& Fiske, D. W. (1959). Convergent and Discriminant Validity by Multitrait-Multimethod Matrix. Psychological Bulletin, 56, 81-105. https://doi.org/10.1037/h0046016

Cao, M., \& Zhang, Q. (2011). Supply Chain Collaboration: Impact on Collaborative Advantage and Firm Performance. Journal of Operations Management, 29, No. 3. https://doi.org/10.1016/j.jom.2010.12.008

Chan, F. T. S. (2003). Performance Measurement in a Supply Chain. The International Journal of Advanced Manufacturing Technology, 21, 534-548. 
https://doi.org/10.1007/s001700300063

Chen, J. C., \& Cox, R. A. (2012). Value Stream Management for Lean Office-A Case Study. American Journal of Industrial and Business Management, 2, 17-29. https://doi.org/10.4236/ajibm.2012.22004

Chin, C.-L., \& Yao, G. (2014). Convergent Validity. In A. C. Michalos (Eds.), Encyclopedia of Quality of Life and Well-Being Research. Dordrecht: Springer. https://doi.org/10.1007/978-94-007-0753-5_573

Christopher, M. (1998). Logistics and Supply Chain Management: Strategies for Reducing Cost and Improving Service. Financial Times, London: Prentice-Hall.

CIO Leadership (2009). Maximising the Value of Supplier Relationships. https://info.vantagepartners.com/insights/cio-leadership-interview-maximising-the-val ue-of-supplier-relationships

Cohen, R. J., \& Swerdlik, M. E. (2005). Psychological Testing and Assessment: An Introduction to Tests and Measurement (6th ed.). New York: McGraw-Hill.

Cumby, J., \& Conrod, J. (2001). Non-Financial Performance Measures in the Canadian Biotechnology Industry. Journal of Intellectual Capital, 2, 261-272. https://doi.org/10.1108/14691930110400001

Daoud, J. I. (2017). Multicollinearity and Regression Analysis. Journal of Physics: Conference Series, 949, 012009. https://doi.org/10.1088/1742-6596/949/1/012009

Dave, Y., \& Sohani, N. (2019). Improving Productivity through Lean Practices in Central India-Based Manufacturing Industries. International Journal of Lean Six Sigma, 10, 601-621. https://doi.org/10.1108/IJLSS-10-2017-0115

de Araújo, M. C. B., Alencar, L. H., \& Viana, J. C. (2015). Structuring a Model for Supplier Selection. Management Research Review, 38, 1213-1232.

https://doi.org/10.1108/MRR-04-2014-0076

Devon, H. A., Block, M. E., Moyle-Wright, P., Ernst, D. M., Hayden, S. J., Lazzara, D. J., Savoy, S. M., \& Kostas-Polston, E. (2007). A Psychometric Toolbox for Testing Validity and Reliability. Journal of Nursing Scholarship, 39, No. 2.

https://doi.org/10.1111/j.1547-5069.2007.00161.x

Dey, C. K. (2016). Strategies to Reduce Supply Chain Disruptions in Ghana. PhD. Thesis, Minneapolis, MN: Walden University.

Duhaylongsod, J. B., \& De Giovanni, P. (2019). The Impact of Innovation Strategies on the Relationship between Supplier Integration and Operational Performance. International Journal of Physical Distribution \& Logistics Management, 49, 156-177. https://doi.org/10.1108/IJPDLM-09-2017-0269

Ehrlich, B. H. (2002) Transactional Six Sigma Servicing, Leveraging Manufacturing Concepts to Achieve World-Class Service. Boca Raton, FL: St. Lucie Press.

Ekici, A. (2013). An Improved Model for Supplier Selection under Capacity Constraint and Multiple Criteria. International Journal of Production Economics, 141, 574-581. https://doi.org/10.1016/j.ijpe.2012.09.013

Field, A. P. (2009). Discovering Statistics Using SPSS: (and Sex and Drugs and Rock " $n$ " Roll) (3rd ed.). London: Sage.

Flynn, B., Huo, B., \& Zhao, X. (2010). The Impact of Supply Chain Integration on Performance: A Contingency and Configuration Approach. Journal of Operations Management, 28, 58-71. https://doi.org/10.1016/j.jom.2009.06.001

Foerstl, K., Franke, H., \& Zimmermann, F. (2016). Mediation Effects in the "Purchasing and Supply Management (PSM) Practice-Performance Link": Findings from a Me- 
ta-Analytical Structural Equation Model. Journal of Purchasing \& Supply Management, 22, 351-366. https://doi.org/10.1016/j.pursup.2016.08.001

Forkmann, S., Henneberg, S. C., Naude, P., \& Mitrega, M. (2016). Supplier Relationship Management Capability: A Qualification and Extension. Industrial Marketing Management, 57, 185-200. https://doi.org/10.1016/j.indmarman.2016.02.003

Fornell, C., \& Larcker, D. (1981). Structural Equation Models with Unobservable Variables and Measurement Error: Algebra and Statistics. Journal of Marketing Research, 18, 382-388. https://doi.org/10.1177/002224378101800313

Frappaolo, C. (2006). Knowledge Management. West Sussex: Capstone Publishing Ltd. (A Wiley Company).

Ganeshan, R., \& Harrison, T. P. (1999). An Introduction to Supply Chain Management (pp. 1-2).

Ganiyu, S. A., Yu, D., Xu, C., \& Providence, A. M. (2020). The Impact of Supply Chain Risks and Supply Chain Risk Management Strategies on Enterprise Performance in Ghana. Open Journal of Business and Management, 8, 1491-1507.

https://doi.org/10.4236/ojbm.2020.84095

Gavirneni, S., Kapuscinski, R., \& Tayur, S. (1999). Value of Information in Capacitated Supply Chains. Management Science, 45, 16-24. https://doi.org/10.1287/mnsc.45.1.16

Giunipero, L. C., Denslow, D., \& Eltantawy, R. (2005). Purchasing/Supply Chain Management Flexibility: Moving to an Entrepreneurial Skill Set. Industrial Marketing Management, 34, 602-613. https://doi.org/10.1016/j.indmarman.2004.11.004

Gregory, R. J. (2007). Psychology Testing: History, Principles and Application (5th ed.) Boston, MA: Ally \& Bacon.

Haier Jr., J., Black, W., Babin, B., \& Anderson, R. (2014). Multivariate Data Analysis (7th ed.). Harlow: Pearson Education Ltd.

Hair Jr., Black, J. F., Babin, W. C., Anderson, R. E., \& Tatham, R. L. (2006). Multivariate data Analysis (6th ed.). Upper Saddle River, NJ: Pearson-Prentice Hall.

Handfield, R. B., \& Pannesi, R. T. (1992). An Empirical Study of Delivery Speed and Reliability. International Journal of Operations \& Production Management, 12, 58-72. https://doi.org/10.1108/01443579210009069

Hooper, D., Coughlan, J., \& Mullen, M. R. (2008). Equation Modelling: Guidelines for Determining Model Fit. Electronic Journal of Business Research Methods, 6, 53-60.

Houlihan, J. B. (1984). Supply Chain Management. In Proceedings of the 19th International Technical Conference (101-110). BPICS.

Hoyle, R. H., \& Panter, A. T. (1995). Writing about Structural Equation Modeling. In R. H. Hoyle (Ed.), Structural Equation Modelling (pp. 158-176). Thousand Oaks, CA: Sage.

Hubley, A. M. (2014). Discriminant Validity. In A. C. Michalos (Ed.), Encyclopedia of Quality of Life and Well-Being Research. Dordrecht: Springer. https://doi.org/10.1007/978-94-007-0753-5_751

Hubley, A. M., \& Zumbo, B. D. (1996). A Dialectic on Validity: Where We Have Been and Where We Are Going. The Journal of General Psychology, 123, 207-215. https://doi.org/10.1080/00221309.1996.9921273

Ivens, B. S. (2005). Flexibility in Industrial Service Relationships: The Construct, Antecedents, and Performance Outcomes. Industrial Marketing Management, 34, 566-576. https://doi.org/10.1016/j.indmarman.2004.10.007

Jajja, M. S. S., Kannan, V. R., Brah, S. A., \& Hassan, S. Z. (2017). Linkages between Firm 
Innovation Strategy, Suppliers, Product Innovation, and Business Performance: Insights from Resource Dependence Theory. International Journal of Operations \& Production Management, 37, 1054-1075. https://doi.org/10.1108/IJOPM-09-2014-0424

Joshi, S., Kharat, M., Raut, R., Kamble, S., \& Kamble, S. (2017). To Examine the Relationships between Supplier Development Practices and Supplier-Buyer Relationship Practices from the Supplier's Perspective. Benchmarking: An International Journal, 24, 1309-1336. https://doi.org/10.1108/BIJ-01-2016-0006

Kafetzopoulos, D., Gotzamani, K., \& Skalkos, D. (2019). The Relationship between EFQM Enablers and Business Performance: The Mediating Role of Innovation. Journal of Manufacturing Technology Management, 30, 684-706. https://doi.org/10.1108/JMTM-06-2018-0166

Kar, A. K., \& Pani, A. K. (2014) Exploring the Importance of Different Supplier Selection Criteria. Management Research Review, 37, 89-105. https://doi.org/10.1108/MRR-10-2012-0230

Kim, S.-K. (2015). Lean Initiative Practice for Supplier Developments in Philippines. International Journal of Lean Six Sigma, 6, 349-368. https://doi.org/10.1108/IJLSS-12-2014-0042

Kisperska-Moron, D., \& De Haan, J. (2011). Improving Supply Chain Performance to Satisfy Final Customers: "Leagile" Experiences of a Polish Distributor. International Journal of Production Economics, 133, 127-134. https://doi.org/10.1016/j.ijpe.2009.12.013

Kline, R. B. (2005). Principles and Practice of Structural Equation Modeling (2nd ed.). New York: Guilford.

Kumar, C., \& Nambirajan, T. (2013). An Integrated Model for Supply Chain Management Components, Supply Chain Performance and Organizational Performance: Purification and Validation of a Measurement Instrument. The Journal of Contemporary Management Research, 8, 37-56.

Lamming, R. (1996). Squaring Lean Supply with Supply Chain Management. International Journal of Operating \& Production Management, 16, 183-196. https://doi.org/10.1108/01443579610109910

Li, S., Ragu-Nathan, B., Ragu-Nathan, T. S., \& Subba Rao, S. (2006). The Impact of Supply Chain Management Practices on Competitive Advantage and Organizational Performance. Omega, 34, 107-124. https://doi.org/10.1016/j.omega.2004.08.002

Liaw, S., Chen, G., \& Huang, H. (2008). Users' Attitudes toward Web-Based Collaborative Learning Systems for Knowledge Management. Computers and Education, 50, 950-961. https://doi.org/10.1016/j.compedu.2006.09.007

Lin, C., Chow, W. S., Madu, C. N., Kuei, C.-H., \& Yu, P. P. (2005). A Structural Equation Model of Supply Chain Quality Management and Organizational Performance. International Journal of Production Economics, 96, 355-365. https://doi.org/10.1016/j.ijpe.2004.05.009

Liu, Y., Huang, Y., Luo, Y., \& Zhao, Y. (2012) How Does Justice Matter in Achieving Buyer-Supplier Relationship Performance? Journal of Operations Management, 30, 355-367. https://doi.org/10.1016/j.jom.2012.03.003

Maheshwari, B., Kumar, V., \& Kumar, U. (2006). Optimizing Success in Supply Chain Partnerships. Journal of Enterprise Information Management, 19, 277-291. https://doi.org/10.1108/17410390610658469

Marodin, G. A., Tortorella, G. L., Frank, A. G., \& Filho, M. G. (2017). The Moderating Effect of Lean Supply Chain Management on the Impact of Lean Shop Floor Practices 
on Quality and Inventory. Supply Chain Management: An International Journal, 22, 473-485. https://doi.org/10.1108/SCM-10-2016-0350

Mekong Capital (2004). Introduction to Lean Manufacturing for Vietnam, 4 June. http://www.industryweek.com/CurrentArticle/asp/article.asp?ArticleID=1589

Mettler, T., \& Rohner, P. (2009). Supplier Relationship Management: A Case Study in the Context of Health Care. Journal of Theoretical and Applied Electronic Commerce Research, 4, 58-71. https://doi.org/10.4067/S0718-18762009000300006

Minh, K. S., Zailani, S., Iranmanesh, M., \& Heidari, S. (2019). Do Lean Manufacturing Practices Have Negative Impact on Job Satisfaction? International Journal of Lean Six Sigma, 10, 257-274. https://doi.org/10.1108/IJLSS-11-2016-0072

Nawanir, G., Kong Teong, L., \& Othman, S. N. (2013). Impact of Lean Practices on Operations Performance and Business Performance: Some Evidence from Indonesian Manufacturing Companies. Journal of Manufacturing Technology Management, 24, 1019-1050. https://doi.org/10.1108/JMTM-03-2012-0027

Ndubisi, N. O., Jantan, M., Hing, L. C., \& Ayub, M. S. (2005). Supplier Selection and Management Strategies and Manufacturing Flexibility. The Journal of Enterprise Information Management, 18, 330-349. https://doi.org/10.1108/17410390510592003

Netemeyer, R. G., Bearden, W. O., \& Sharma, S. (2003). Scaling Procedures: Issues and Applications. Thousand Oaks, CA: SAGE. https://doi.org/10.4135/9781412985772

Qrunfleh, S., Tarafdar, M., \& Ragu-Nathan, T. S. (2012) Examining Alignment between Supplier Management Practices and Information Systems Strategy. Benchmarking: An International Journal, 19, 604-617. https://doi.org/10.1108/14635771211258034

Ringle, C. M., Wende, S., \& Becker, J.-M. (2015). SmartPLS 3. Bönningstedt: SmartPLS. http://www.smartpls.com

Rizzardo, D., \& Brooks, R. (Eds.) (2008). Understanding Lean Manufacturing. College Park, MD: MarylandTechnology Extension Service (MTES) Tech Tip.

Ross \& Associates Environmental Consulting (2008). Working Smart for EPA, Improving State Agency Processes with Lean in Government Series.

Sahoo, S., \& Yadav, S. (2018). Lean Production Practices and Bundles: A Comparative Analysis. International Journal of Lean Six Sigma, 9, 374-398. https://doi.org/10.1108/IJLSS-01-2017-0002

Samawi, G., Abushaikha, I., Salhieh, L., Mdanat, M., \& Al-Rashid, A. (2019). Aligning Business Strategic Priorities and Purchasing Practices in Industrial Firms: Evidence from an Emerging Economy. Theoretical Economic Letters, 9, 709-736. https://doi.org/10.4236/tel.2019.94047

Sambamurthy, V., Bharadwaj, A., \& Grover, V. (2003). Shaping Agility through Digital Options: Reconceptualizing the Role of Information Technology in Contemporary Firms. MIS Quarterly, 27, 237-263. https://doi.org/10.2307/30036530

Sangwa, N. R., \& Sangwan, K. S. (2018). Development of an Integrated Performance Measurement Framework for Lean Organizations. Journal of Manufacturing Technology Management, 29, 41-48. https://doi.org/10.1108/JMTM-06-2017-0098

Sezhiyan, D. M., \& Nambirajan, T. (2010). Development of Scale to Measure Supplier Selection, Supply Effort Management and Organizational Performance. Asia-Pacific Business Review, 6, 26-37. https://doi.org/10.1177/097324701000600404

Shah, R., \& Ward, P. T. (2007). Defining and Developing Measures of Lean Production. Journal of Operations Management, 25, 785-805.

https://doi.org/10.1016/j.jom.2007.01.019 
Shariff, M. N. M., Peou, C., \& Ali, J. (2010). Moderating Effect of Government Policy on Entrepreneurship and Growth Performance of Small-Medium Enterprises in Cambodia. International Journal of Business and Management Science, 3, 57.

Singh, D. K., \& Singh, S. (2015). Procurement Strategy for Manufacturing and JIT. International Journal of Engineering Research and Development, 11, 10-17.

Singh, S., \& Garg, D. (2011). Attributes in JIT Purchasing. AKGEC Journal of Technology, 2, 29-33.

So, S., \& Sun, H. (2010). Supplier Integration Strategy for Lean Manufacturing Adoption in Electronic-Enabled Supply Chains. Supply Chain Management: An International Journal, 15, 474-487. https://doi.org/10.1108/13598541011080455

Spiliotopoulou, G. (2009). Reliability Reconsidered: Cronbach's Alpha and Paediatric Assessment in Occupational Therapy. Australian Occupational Therapy Journal, 56, No. 3. https://doi.org/10.1111/j.1440-1630.2009.00785.x

Steiger, J. H. (2007). Understanding the Limitations of Global Fit Assessment in Structural Equation Modeling. Personality and Individual Differences, 42, 893-898. https://doi.org/10.1016/j.paid.2006.09.017

Taj, S., \& Morosan, C. (2011). The Impact of Lean Operations on the Chinese Manufacturing Performance. Journal of Manufacturing Technology Management, 22, 223-240. https://doi.org/10.1108/17410381111102234

Tasmin, R., \& Woods, P. (2007). Relationship between Corporate Knowledge Management and the Firm's Innovation Capability. International Journal of Services Technology and Management, 8, 62-79. https://doi.org/10.1504/IJSTM.2007.012219

Tsai, J. F. (2007). An Optimization Approach for Supply Chain Management Models with Quantity Discount Policy. European Journal of Operational Research, 177, 982-994. https://doi.org/10.1016/j.ejor.2006.01.034

Upton, D. M. (1995). What Really Makes Factories Flexible? Harvard Business Review, 73, 74-84.

Vereecke, A., \& Muylle, S. (2006). Performance Improvement through Supply Chain Collaboration in Europe. International Journal of Operations \& Production Management, 26, 1176-1198. https://doi.org/10.1108/01443570610705818

Vickery, S., Calantone, R., \& Droge, C. (1999). Supply Chain Flexibility: An Empirical Study. The Journal of Supply Chain Management, 35, 16-24.

https://doi.org/10.1111/j.1745-493X.1999.tb00058.x

Vinodh, S., \& Joy, D. (2012) Structural Equation Modeling of Sustainable Manufacturing Practices. Clean Technologies and Environmental Policy, 14, 79-84. https://doi.org/10.1007/s10098-011-0379-8

Wang, S., \& Noe, R. (2010). Knowledge Sharing: A Review and Directions for Future Research. Human Resource Management Review, 20, 115-131. https://doi.org/10.1016/j.hrmr.2009.10.001

Wen, Z. L., Hau, K. T., \& Marsh, H. W. (2004). Structural Equation Model Testing: Cutoff Criteria for Goodness of Fit and Chi Square. Acta Psychologica Sinica, 36, 186-194.

White, G. P. (1996). A Meta-Analysis Model of Manufacturing Capabilities. Journal of Operations Management, 14, 315-331. https://doi.org/10.1016/S0272-6963(96)00096-4

Wickramasinghe, G. L. D., \& Wickramasinghe, V. (2017). Implementation of Lean Production Practices and Manufacturing Performance: The Role of Lean Duration. Journal of Manufacturing Technology Management, 28, 531-550.

https://doi.org/10.1108/JMTM-08-2016-0112 
Womack, J., Jones, D., \& Roos, D. (1990). The Machine that Changed the World: The Story of Lean Production. New York: Harper Perennial.

Wu, Y. C. (2003). Lean Manufacturing: A Perspective of Lean Suppliers. International Journal of Operations \& Production Management, 23, 1349-1376. https://doi.org/10.1108/01443570310501880

Yamane, T. (1967). Statistics: An Introductory Analysis (2nd ed.). New York: Harper and Row

Yang, M. G., Hong, P., \& Modi, S. B. (2011). Impact of Lean Manufacturing and Environmental Management on Business Performance: An Empirical Study of Manufacturing Firms. International Journal of Production Economics, 129, 251-261. https://doi.org/10.1016/j.ijpe.2010.10.017

Yoo, W., Mayberry, R., Bae, S., Singh, K., He, Q. P., \& Lillard Jr., J. W. (2014). A Study of Effects of Multicollinearity in the Multivariate Analysis. International Journal of Applied Science and Technology, 4, 9-19.

Yu, T., Lu, T., \& Liu, T. (2010). Exploring Factors That Influence Knowledge Sharing Behavior via Web Logs. Computers in Human Behavior, 26, 32-41.

https://doi.org/10.1016/j.chb.2009.08.002 